\title{
Alkyne-substituted diminazene as G-quadruplex binders with anticancer activities
}

Changhao Wang ${ }^{1}$, Brandon Carter-Cooper ${ }^{2}$, Yixuan Du ${ }^{1}$, Jie Zhou ${ }^{1,3,4}$, Musabbir. A. Saeed ${ }^{1}$, Jinbing Liu ${ }^{1}$, Min Guo ${ }^{1}$, Benjamin Roembke ${ }^{1}$, Clinton Mikek$^{5}$, Edwin A. Lewis ${ }^{5}$, Rena G. Lapidus ${ }^{2}$ and Herman O. $\operatorname{Sintim}^{1,3,4 *}$

${ }^{1}$ Department of Chemistry and Biochemistry, University of Maryland, College Park, Maryland 20742, USA.

${ }^{2}$ Translational Core Laboratory, University of Maryland Greenebaum Cancer Center, 655 W. Baltimore Street, Baltimore,

MD 21201, USA.

${ }^{3}$ Department of Chemistry, Purdue University, 560 Oval Drive, West Lafayette, IN 47907, USA.

${ }^{4}$ Center for Drug Discovery, Purdue University, 720 Clinic Drive, West Lafayette, IN 47907, USA.

${ }^{5}$ Department of Chemistry, Mississippi State University, Mississippi State, MS 39762, USA.

*Corresponding author email: hsintim@purdue.edu

(C) 2016. This manuscript version is made available under the Elsevier user license http://www.elsevier.com/open-access/userlicense/1.0/ 


\section{Abstract}

G-quadruplex ligands have been touted as potential anticancer agents, however, none of the reported G-quadruplex-interactive small molecules have gone past phase II clinical trials. Recently it was revealed that diminazene (berenil, DMZ) actually binds to G-quadruplexes 1000 times better than DNA duplexes, with dissociation constants approaching $1 \mathrm{nM}$. DMZ however does not have strong anticancer activities. In this paper, using a panel of biophysical tools, including NMR, FRET melting assay and FRET competition assay, we discovered that monoamidine analogues of DMZ bearing alkyne substitutes selectively bind to G-quadruplexes. The lead DMZ analogues were shown to be able to target $c-M Y C$ G-quadruplex both in vitro and in vivo. Alkyne DMZ analogues display respectable anticancer activities (single digit micromolar $\mathrm{GI}_{50}$ ) against ovarian (OVCAR-3), prostate (PC-3) and triple negative breast (MDA-MB-231) cancer cell lines and represent interesting new leads to develop anticancer agents. 


\section{Introduction}

Cancers of the human reproductive organs, such as ovarian, prostate and breast, kill millions of people annually worldwide. Although there are several therapeutics against these cancers, ${ }^{1}$ aggressive forms remain problematic to treat. For example, although there are myriad hormone-based therapeutics against breast cancer, ${ }^{2}$ hormone insensitive breast cancer such as triple negative breast cancer remains difficult to treat. $^{3}$

G-quadruplex structures in both DNA and RNA are emerging as important regulatory elements that control diverse processes in the cell, ranging from telomere maintenance, ${ }^{4}$ gene expression, ${ }^{5}$ translation, ${ }^{6}$ alternative splicing, ${ }^{7}$ RNA metabolism ${ }^{8}$ and protein sequestration. ${ }^{9}$ Additionally G-quadruplex elements (both DNA and RNA) in the cell have been postulated to bind to and activate heme to promote oxidative damage. ${ }^{10}$ Such enzymatic function of G-quadruplexes ${ }^{11}$ could exacerbate neurodegenerative diseases. ${ }^{10}$ Due to the expanding role of G-quadruplexes in biology, ${ }^{12}$ there has been an explosion of research activities dedicated to the discovery of G-quadruplex ligands. ${ }^{13}$ Small molecules that stabilize the G-quadruplex structure have been shown to inhibit telomere extension ${ }^{14}$ and transcription of oncogenic genes (such as $c-M Y C,{ }^{15} c-k i t,{ }^{16}{ }^{K} R A S^{5 b}$ ) and hence these molecules have the potential to be used as antineoplastics. ${ }^{417}$ Beyond potential use as anticancer agents, G-quadruplex ligands have also been shown to inhibit HIV replication. ${ }^{18}$

We have been interested in repurposing drugs that are used in both human and veterinary medicine for other indications for anticancer therapy because we believe that the translational potential for such drugs or analogues thereof is high, since the molecules are already in clinical use. Along this line, we recently reported that diminazene (DMZ in Fig. 1), a drug used to treat sleeping sickness (animal trypanosomiasis), and which was formerly considered as selective AT-rich duplex binder (via minor 
groove) is indeed a potent G-quadruplex binder with nanomolar dissociation constant $\left(K_{\mathrm{d}}\right) \cdot{ }^{19} \mathbf{D M Z}$ binds to DNA minor groove with a $K_{d}$ of $1 \mu \mathrm{M}$ so it appears that $\mathbf{D M Z}$ is more selective for G-quadruplex than duplex DNA. ${ }^{19(\mathrm{a})}$ Nonetheless a $K_{d}$ of $1 \mu \mathrm{M}$ for duplex DNA would limit the targeting of G-quadruplexes by DMZ in the complex cellular environment, where the concentration of duplex DNA is several orders of magnitude greater than G-quadruplexes. We had earlier observed that the monoamidine analogue of DMZ (DMZ1 in Fig. 1) could also bind to G-quadruplexes, albeit not as potent as DMZ. ${ }^{19(a)}$ Importantly DMZ1 only had a weak affinity for duplex DNA $\left(K_{d}=34 \mu \mathrm{M} \text { for AT-rich duplex DNA }\right)^{19(\mathrm{a})}$, suggesting that perhaps DMZ1 was a better starting point for developing G-quadruplex interactive anti-cancer agents. A focused library of DMZ1 analogues (Fig. 1), whereby a $\pi$-moiety was appended to the parent DMZ1, were easily prepared via Sonogashira coupling and then triazene formation. Herein, we reveal that DMZ and monoamidine analogue, DMZ1, do not have anticancer properties but alkyne analogues of DMZ have respectable to good anticancer properties against ovarian, prostate and triple negative breast cancers.<smiles>[R]c1ccc(NN=Nc2ccc(C(=N)N)cc2)cc1</smiles><smiles>[R]c1cccc(NN=Nc2ccc(C(=N)N)cc2)c1</smiles>

$$
\begin{aligned}
& \text { (DMZ) } R_{1}=-\xi \widehat{N}_{N H}^{N_{2}} \quad\left(\text { DMZ1) } R_{1}=-\xi \cdot H\right. \\
& \text { (DMZ2) } R_{1}=-\xi=N \quad \text { (DMZ3) } R_{1}=-\xi=
\end{aligned}
$$<smiles>[R3]c1ccccc1N/N=N/c1ccc(C(=N)N)cc1</smiles>

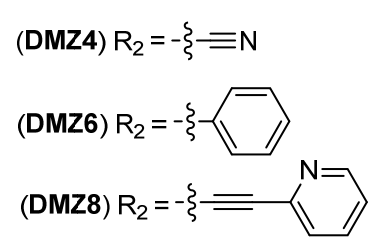
(DMZ5) $R_{2}=-\xi \equiv$ (DMZ7) $\mathrm{R}_{2}=-\xi=\square$<smiles>COCC#CC#Cc1ccc(F)cc1</smiles>

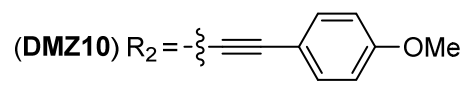

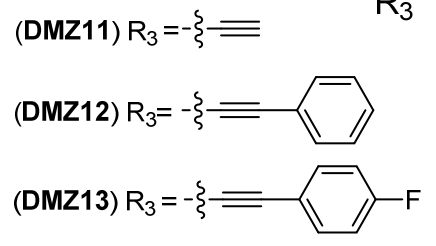<smiles>[R]NN=Nc1ccc(C(=N)N)cc1</smiles>

Fig. 1 The structures of diminazene (DMZ) analogues. 


\section{Results and discussion}

\section{Design and synthesis of alkyne-substituted DMZ analogues as G-quadruplex binders}

To aid future optimizations of the alkyne DMZ analogues as anticancer agents, we sought to verify that like the parent DMZ, these compounds also bind to G-quadruplexes. Also, we asked if the compounds were selective for G-quadruplexes over DNA duplexes. Since DMZ requires both amidine groups to bind to duplex DNA, removing one amidine group will reduce duplex DNA binding affinity. However, the G-quadruplex surface has more room to accommodate on extended pi-surface. We therefore extended the parent DMZ with addition aromatic surface while maintained one amidine for solubility concern. Sonogashira coupling strategy allowed us to generate alkyne-substituted DMZ analogues in a timely and economic manner. Details of synthetic pathway were illustrated in experimental section. We also explored the effects of substitutions on the aromatic rings by incorporating fragments such as pyridine, fluorine and methoxy groups. These groups are commonly found in drugs. Pyridine is a mimic of phenyl group, but has an enhanced aqueous solubility arising from the nitrogen in the pyridine forming hydrogen bonds with water. Additionally the nitrogen in the pyridine ring could interact with the DNA nucleobases via hydrogen bonding. Fluorine and the methoxy groups could also accept hydrogen bonds from water and/or the DNA target. A second criteria that we used for selecting the analogs was synthetic tractability and the commercial availability of that starting materials.

Initial attempts to characterize the binding of the analogues using isothermal titration calorimetry (ITC) was not very successful due to the low solubility of the compounds in buffer (see SI, Table S2, Fig. S1 and S2). Others have used FRET melting of fluorophore-labeled G-quadruplexes to determine the binding of ligands to G-quadruplexes and also selectivity between G-quadruplexes and duplexes, so we decided to 
adopt this protocol. ${ }^{20}$ Thus, we investigated the change in melting temperature $\left(T_{1 / 2}\right)$ by fluorescence resonance energy transfer (FRET) assay (Fig. 2 and 3). We chose dual-labeled F21T, c-MYC, c-kit2 and $\mathrm{k}-R A S 21 R$ because c-MYC G-quadruplex affects the c-MYC transcriptional activity ${ }^{21}$ while $c$-kit and $k$-RAS G-quadruplexes control the expression of oncogenic $c-k i t^{16}$ and $K R A S^{5}$ proteins and F21T is a good model for telomere. ${ }^{5}$ 26-mer DNA (hairpin) is a good model to determine if the ligands could also bind to duplexes $^{22}$. The FRET-labeled oligonucleotides used in this study have also been used by others and shown to be well-behaved in determining the potency of G-quadruplex ligands. ${ }^{20}$ 


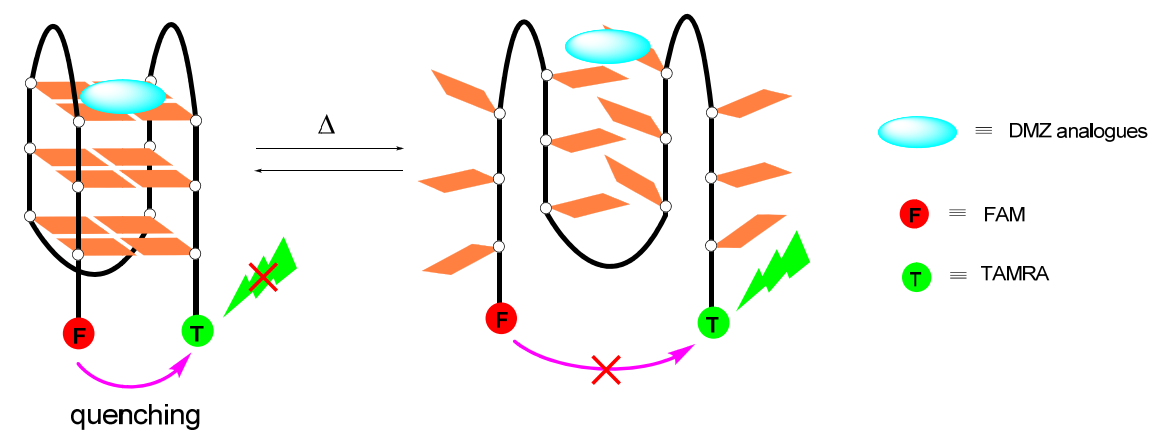

Fig. 2 FRET model of study.

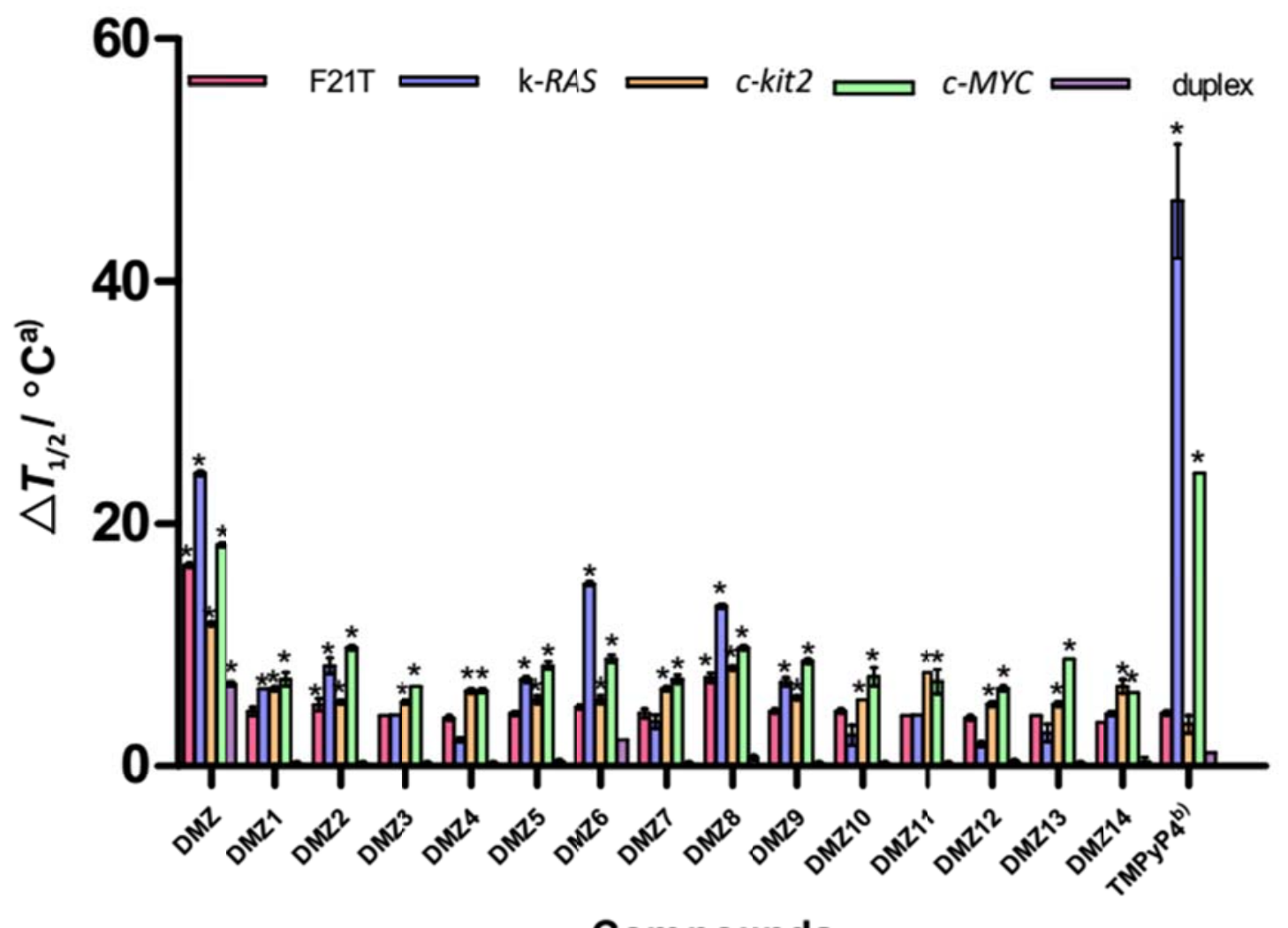

Compounds

Fig. 3 FRET stabilization temperature $\left(\triangle T_{1 / 2}\right)$ of various G-quadruplex DNA with DMZ analogues and TMPyP4. aG-quadruplex DNA: F21T (5'-FAM-GGG TTA GGG TTA GGG TTA GGG-TAMRA-3'), c-kit2 (5'-FAM-CCC GGG CGG GCG CGA GGG AGG GGA GG-TAMRA-3'), k-RAS21R (5'-FAM-AGG GCG GTG TGG GAA GAG GGA-TAMRA-3'), c-MYC (5'-FAM-TGA GGG TGG GTA GGG TGG GTA A-TAMRA-3'). Duplex 26-mer (5'FAM-TAT AGC TAT ATT TTT TTA TAG CTA TA-TAMRA-3'). Conditions: dual-labeled DNA (0.4 $\mu \mathrm{M})$, DMZ analogues $(4 \mu \mathrm{M})$, potassium cacodylate buffer $(60 \mathrm{mM}, \mathrm{pH} 7.2) . \Delta T_{1 / 2}$ is calculated by melting temperature in the presence and absence of DMZ analogues. ${ }^{b}$ For TMPyP4, $0.4 \mu \mathrm{M}$ dual-labeled DNA and TMPyP4 were applied to get meaningful melting temperatures. ${ }^{*} \Delta T_{1 / 2}$ is larger than $5^{\circ} \mathrm{C}$.

TMPyP4, a prototypical G-quadruplex ligand was the most stabilizing ligand (note that a lower concentration of TMPyP4 was used in the FRET melting assay, compared to the amidine ligands). Of the 
tested triazenes, DMZ, which has two amidine groups, was the best stabilizer of the tested G-quadruplexes but showed low selectivity between G-quadruplexes and duplex DNA. For example, DMZ could stabilize k-RAS21R but could also stabilize double-stranded DNA, see Fig. 3. Removing one of the amidine groups from DMZ to afford compound DMZ1 reduced affinity for duplex DNA $\left(\triangle T_{1 / 2}<1\right.$ ${ }^{\circ} \mathrm{C}$ for double-stranded DNA). Contrary to our initial hypothesis that adding a $\pi$-moiety to DMZ1 would increase G-quadruplex binding, the addition of an alkyne, cyano or phenyl groups to compound DMZ1 did not afford an analogue with a more superior G-quadruplex stabilization property than DMZ1 (see Fig. 3 and Table S1 in SI). Encouraging, however, was the observation that DMZ1 and alkyne analogues (but not the control compound TMPyP4 or DMZ) were more selective for G-quadruplex over duplex DNA (see Fig. 4 and Table S1 in SI.). We determined the melting temperature of fluorescently-labelled c-MYC in the presence of fixed ligand concentration and increasing concentrations of non-fluorescent double-stranded DNA. When compound DMZ1 or alkyne derivatives were used as ligands, adding up to 500 equivalence of double-stranded DNA did not affect the $T_{1 / 2}$ of $c-M Y C$, in agreement with the FRET melting data (Fig. 3), which showed that the compounds stabilized G-quadruplexes but not duplex DNA. For DMZ or TMPyP4 however, increasing the amount of duplex DNA resulted in a lower $\Delta \mathrm{T}_{1 / 2}($ se Fig. 4). 


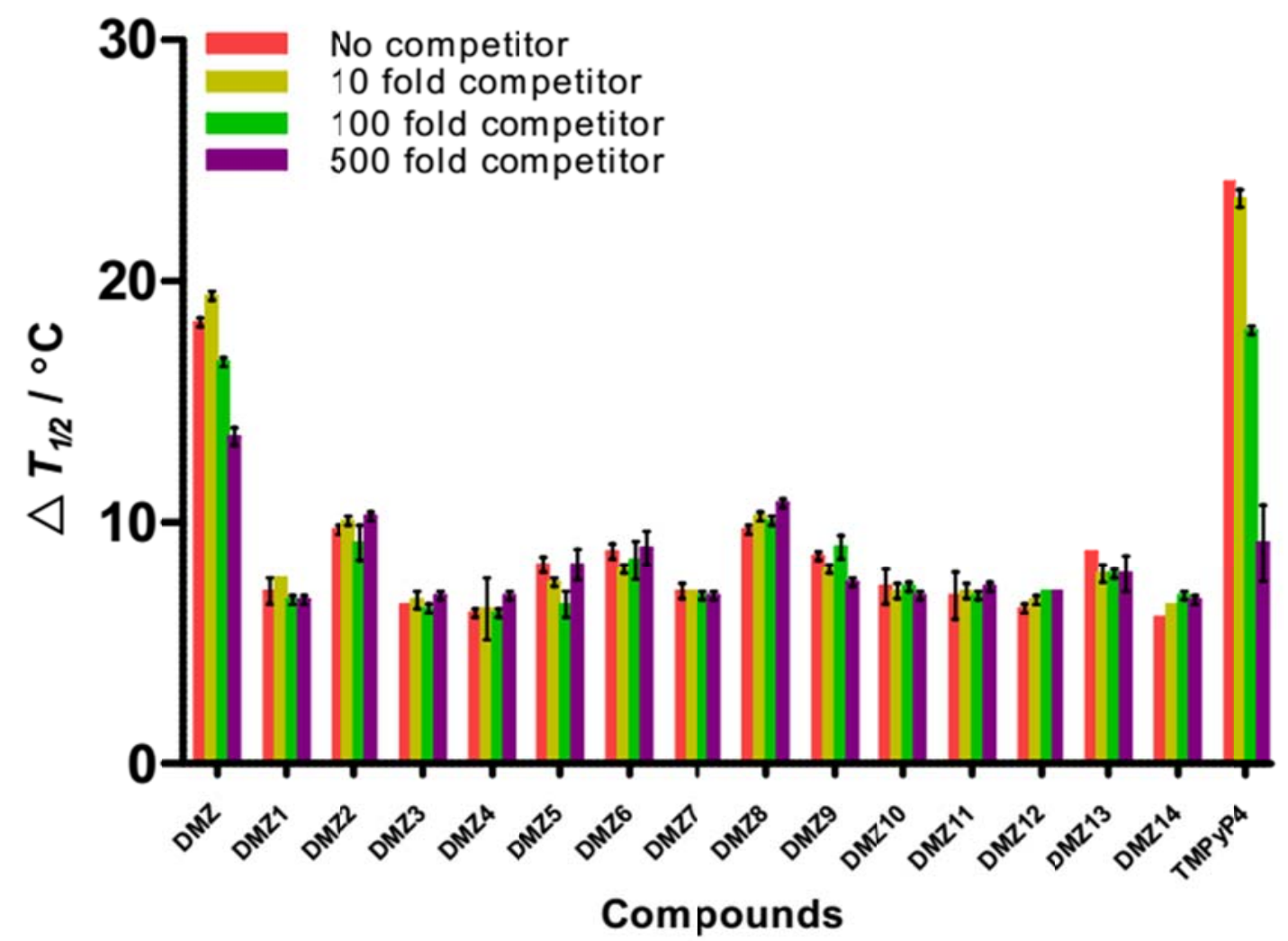

Fig. 4 FRET-melting competition results at $4 \mu \mathrm{M} \mathrm{DMZ}$ analogues in the presence of dual-labeled c-MYC $(0.4$ $\mu \mathrm{M})$ and competitor unlabeled ds-DNA $(0 \mu \mathrm{M}, 4 \mu \mathrm{M}, 40 \mu \mathrm{M}$ and $200 \mu \mathrm{M}) . \Delta T_{1 / 2}$ is calculated by melting temperature in the presence and absence of DMZ analogues. $0.4 \mu \mathrm{M}$ TMPyP4 was added to get meaningful melting temperature.

\section{Viability Assay}

The alkyne DMZ analogues only have moderate affinity for G-quadruplexes and so the key question was whether they could inhibit the proliferation of cancer cells, and if that happens to be the case whether the proliferation inhibition would be via G-quadruplex stabilization inside cells. We evaluated the compounds against three human cancer cell lines, ovarian cancer cell (OVCAR-3), prostate cancer cell (PC-3) and triple negative breast cancer cell (MDA-MB-231), using WST-1 assay. A select few compounds were also tested against two human normal cell lines, normal bone marrow (NBM) and normal fibroblast cell (MCR5A) for cytotoxicity. Amongst the first set of DMZ analogues (compounds DMZ1 to 6, and DMZ11), bearing different substituents (cyano, amidine, alkyne and aryl groups), only the alkyne derivatives (DMZ3, DMZ5 and DMZ11) were active (see Table 1, entries iv, vi and xii), albeit 
not very potent. Interestingly DMZ, which potently binds to G-quadruplexes, and the monoamidine analogue DMZ1 were also not effective at inhibiting cancer proliferation. Encouraged by the initial positive results with the alkynes analogues we sought to optimize the anticancer potency and made further alkyne analogues by appending various aromatic moieties to the alkyne to give compounds DMZ7 to 10 and DMZ12 to 14 (see Fig. 1). We initially rationalized that by adding aromatic appendages to the initial alkyne compounds, stacking interactions between the G-quadruplex tetrad and the compounds would increase.

Table 1. Anticancer activity of DMZ analogues with different cancer cell lines.

\begin{tabular}{ccccccc}
\hline & & \multicolumn{5}{c}{ Anticancer activities for different cancer cell lines } \\
Entry & Compound & \multicolumn{5}{c}{$\left(\mathrm{GI}_{50} \pm \mathrm{SD}, \mu \mathrm{M}\right)^{\mathrm{a}}$} \\
\cline { 3 - 7 } & & OVCAR-3 & $\mathrm{PC}-3$ & $\mathrm{MDA}-\mathrm{MB}-231$ & $\mathrm{NBM}$ & MCR5A \\
\cline { 2 - 7 } i & DMZ & $>25$ & $\mathrm{NE}^{\mathrm{b}}$ & $\mathrm{NE}$ & $-^{\mathrm{d}}$ & - \\
ii & DMZ1 & $\mathrm{NE}$ & $\mathrm{NE}$ & $\mathrm{NE}$ & - & - \\
iii & DMZ2 & $\mathrm{NE}$ & $\mathrm{NE}$ & $\mathrm{NE}$ & - & - \\
iv & DMZ3 & $11.8 \pm 1.7$ & $22.5 \pm 8.8$ & $30.2 \pm 1.8$ & - & - \\
v & DMZ4 & $\mathrm{NE}$ & $\mathrm{NE}$ & $\mathrm{NE}$ & - & - \\
vi & DMZ5 & $16.8 \pm 3.1$ & $18.0 \pm 5.7$ & $20.5 \pm 4.2$ & - & - \\
vii & DMZ6 & $\mathrm{NE}$ & $\mathrm{NE}$ & $\mathrm{NE}$ & - & - \\
viii & DMZ7 & $6.5 \pm 2.1$ & $5.8 \pm 0.2$ & $9.5 \pm 1.3$ & - & - \\
ix & DMZ8 & $10.7 \pm 1.5$ & $10.4 \pm 1.4$ & $14.4 \pm 0.9$ & - & - \\
x & DMZ9 & $5.0 \pm 0.1$ & $5.3 \pm 1.6$ & $5.5 \pm 0.1$ & 5.6 & $8.3 \pm 4.0$ \\
xi & DMZ10 & $5.2 \pm 0.4$ & $5.0 \pm 0.9$ & 5.5 & - & - \\
xii & DMZ11 & $>25$ & $>50$ & 23.2 & - & - \\
xiii & DMZ12 & $8.1 \pm 0.5$ & $5.3 \pm 0.2$ & $5.1 \pm 0.4$ & - & - \\
xiv & DMZ13 & $9.5 \pm 2.2$ & $7.4 \pm 0.2$ & $6.2 \pm 1.0$ & $\mathrm{NE}$ & $\mathrm{NE}$ \\
xv & DMZ14 & $\mathrm{NE}$ & $\mathrm{NE}$ & $\mathrm{NE}$ & - & - \\
Xvi & Cisplatin & $4.1 \pm 1.8$ & $10.5 \pm 1.3$ & $11.7 \pm 1.0$ & $>10$ & $0.41 \pm 0.27$ \\
xvii & $\mathbf{1 5}$ & $\mathrm{NE}$ & $\mathrm{NE}$ & $\mathrm{NE}$ & - & - \\
xviii & $\mathbf{1 9}$ & $\mathrm{NE}$ & $\mathrm{NE}$ & $\mathrm{NE}$ & - & - \\
xix & TMPyP4 & $14.6 \pm 5.7$ & $14.0 \pm 5.4$ & $14.3 \pm 4.0$ & 16.8 & $15.2 \pm 6.6$ \\
\hline
\end{tabular}

${ }^{a}$ Human cancer cell lines: ovarian cancer cell (OVCAR-3), prostate cancer cell (PC-3) and breast cancer cell

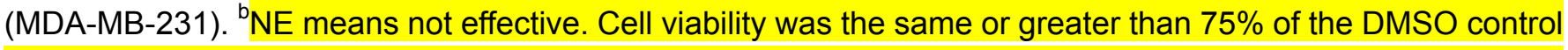
at $20 \mu \mathrm{M}$ compound concentration so accurate $\mathrm{GI}_{50}$ values for these compounds were not determined. ${ }^{\mathrm{c}}$ Cisplatin as a control compound. ${ }^{\mathrm{d}}$ Not determined.

This hypothesis did not pan out as the new alkyne analogues (DMZ7 to 10 and DMZ12 to 14) did not Page 10 
display enhanced G-quadruplex stabilization (see Fig. 4) but the analogues had improved anticancer properties (see Table 1). Of note, the $\mathrm{GI}_{50}$ values of some of the DMZ analogues (DMZ7, DMZ9, DMZ10, DMZ12 and DMZ13) are similar to or better than those of cisplatin against the three tested cancer cell lines (compare entries viii, $\mathrm{x}$, xi, xiii, xiv with xvi in Table 1). Also the $\mathrm{GI}_{50}$ values of some of these analogues were better that TMPyP4, a potent G-quadruplex binder, underscoring the fact that G-quadruplex binding potency alone does not define the potency of these drugs. Cisplatin is an anticancer drug that is still used in the clinic to treat various cancers so the $\mathrm{GI}_{50}$ values that we have obtained for some of the alkyne DMZ derivatives are encouraging and calls for further development of alkyne DMZ analogues as anticancer agents.

To gain some insights into potential toxicities of these DMZ analogues, we proceeded to evaluate analogues DMZ9, DMZ13 TMPyP4 and cisplatin (a control) against two human normal cell lines (NBM and MCR5A) (see entries x, xiv and xix in Table 1). For analogues DMZ9 and TMPyP4, the $\mathrm{GI}_{50}$ values against NBM and MCR5A cells are similar to the three tested cancer cells (hence these compounds might have low therapeutic window). However, and pleasingly, analogue DMZ13 killed the three tested cancer cells with single digit $\mathrm{GI}_{50}$ but was not effective against NBM and MCR5A cells. Cisplatin is used to treat several cancers yet it has a higher toxicity against MCR5A than DMZ9 and DMZ13 (Table 1). To rule out the possibility that the anti-proliferative properties of the alkyne DMZ analogues are not derived from their amine metabolism products, we also tested the anticancer properties of 4-aminobenzamidine and amino alkyne 15 but none of these were active.

Having demonstrated that G-quadruplex-interactive DMZ analogues, bearing alkyne moieties, have anticancer properties and with an eye towards the future development of these molecules, we sought further experiments to cement our belief that these molecules do indeed bind to G-quadruplexes and do so 
selectively. The aforementioned experiments (FRET melting) that investigated the interactions of alkyne analogues of DMZ with G-quadruplexes are indirect. NMR has been demonstrated to be a direct tool to study the interaction between DNA and ligands. ${ }^{23}$ We have used NMR to show that both DMZ9 and DMZ13 interacted with c-kit1, c-MYC G-quadruplex but not duplex. (see Fig. S3 to S5). Since $c-M Y C$ is a key oncogene we performed additional experiments, PCR stop assay (in vitro) and Western analysis of c-MYC expression ${ }^{24}$ (in vivo) in the presence and absence of some of our DMZ analogues (DMZ, DMZ1, DMZ9, DMZ13 and TMPyP4, as control) to determine if the pharmacology of the analogues is at least derived from $c-M Y C$ inhibition.

\section{PCR stop assay}

PCR stop assay, using templates that contain G-quadruplex sequences, has been used by several investigators to demonstrate the binding of ligands to G-quadruplex. ${ }^{25}$ We investigated the effects of analogues DMZ9, DMZ13, DMZ, DMZ1 and TMPyP4 on c-MYC G-quadruplex stabilization via the PCR stop assay. Pu27, Pu27-13,14 and Pu-mutant were used as templates. ${ }^{26}$ Pu27 is contained in the nuclear hypersensitivity element $\mathrm{III}_{1}\left(\mathrm{NHE} \mathrm{III}_{1}\right)$, which controls $80-90 \%$ transcription level of c-MYC. ${ }^{27}$ Pu27-13,14 ${ }^{26}$ and Pu-mutant (see SI) are two mutated Pu27 strands used as control.

In the PCR reaction system, $5 \mu \mathrm{M}$ of Pu27, $5 \mu \mathrm{M}$ of Pu27rev and various concentrations of DMZ1, DMZ9, DMZ13 ( $1 \mu \mathrm{M}, 10 \mu \mathrm{M}, 25 \mu \mathrm{M}, 50 \mu \mathrm{M}$ and $100 \mu \mathrm{M}$ ), DMZ ( $1 \mu \mathrm{M}, 10 \mu \mathrm{M}$ and $25 \mu \mathrm{M})$ and TMPyP4 ( $1 \mu \mathrm{M}$ and $10 \mu \mathrm{M}$ ) were added. The polymerization/extension of oligomers Pu27 and Pu27rev was completely inhibited in the presence of $100 \mu \mathrm{M}$ DMZ9 and DMZ13 (see Fig. 6). Also, DMZ and TMPyP4 showed inhibition at $25 \mu \mathrm{M}$ and $10 \mu \mathrm{M}$, respectively. To eliminate the possibility that the inhibition of DNA extension was caused by the direct inhibition of the polymerase enzyme by the ligands, 
Pu27-13,14 (see Fig. 6) and Pu-mutant were extended in the presence of various concentrations of DMZ9, DMZ13, DMZ and TMPyP4. In both controls, amplified PCR product was observed in the presence of $100 \mu$ M DMZ9, DMZ13 (see Fig.7). However, no PCR product or reduced product was observed in the presence of $10 \mu \mathrm{M}$ TMPyP4 for Pu27-13,14 and Pu-mutant, respectively. On the other hand, the amount of PCR products obtained in the presence of $25 \mu \mathrm{M} \mathrm{DMZ}$ was lower than in the absence of DMZ for Pu27-13,14(see Fig. 7). No changes were observed in Pu-mutant reaction (see Fig. S7). These results were unexpected because both DMZ and TMPyP4 had been shown to bind to both G-quadruplexes and duplex DNA (See Fig. 4) so both compounds would inhibit the extension of Pu27 (containing a G-quadruplex) and Pu27-13,14 (containing duplex). Based on these results, we conclude that the DMZ analogues inhibit the extension of a template containing c-MYC sequences via the stabilization of a G-quadruplex structure in the template and not via direct polymerase inhibition, as observed with the TMPyP4 case. ${ }^{28}$ 

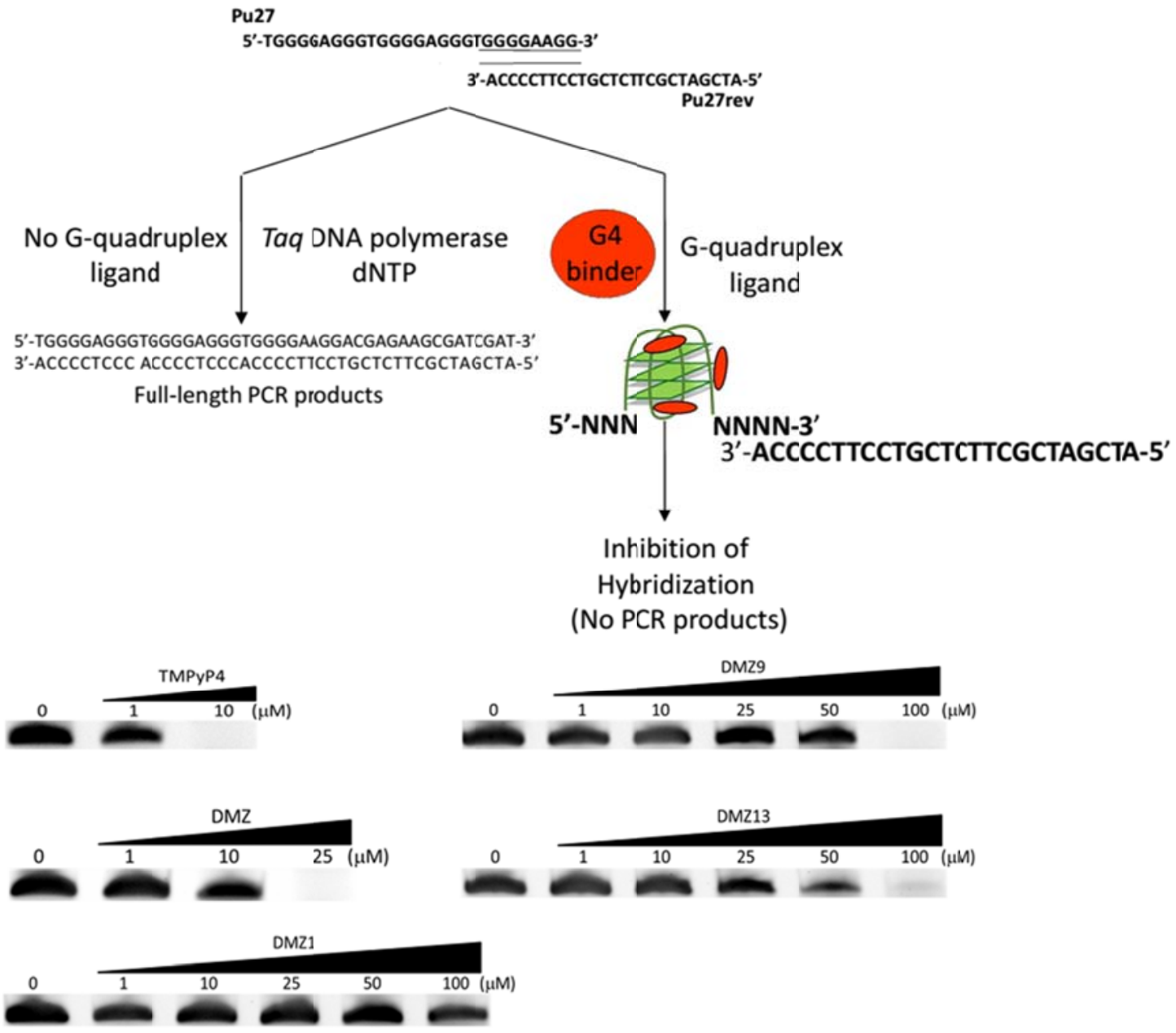

Fig. 6 Effects of DMZ analogues (DMZ1, DMZ 9, DMZ13), DMZ and TMPyP4 on the PCR stop assay with C-MYC Pu27. Compounds were added to the reaction mixture containing 1x PCR buffer (New England Biolabs), $5 \mu \mathrm{M}$ Pu27, $5 \mu \mathrm{M}$ Pu27rev, $200 \mu \mathrm{M}$ dNTPs and 5 units of Taq polymerase (New England Biolabs) separately. No compound added was treated as control. 


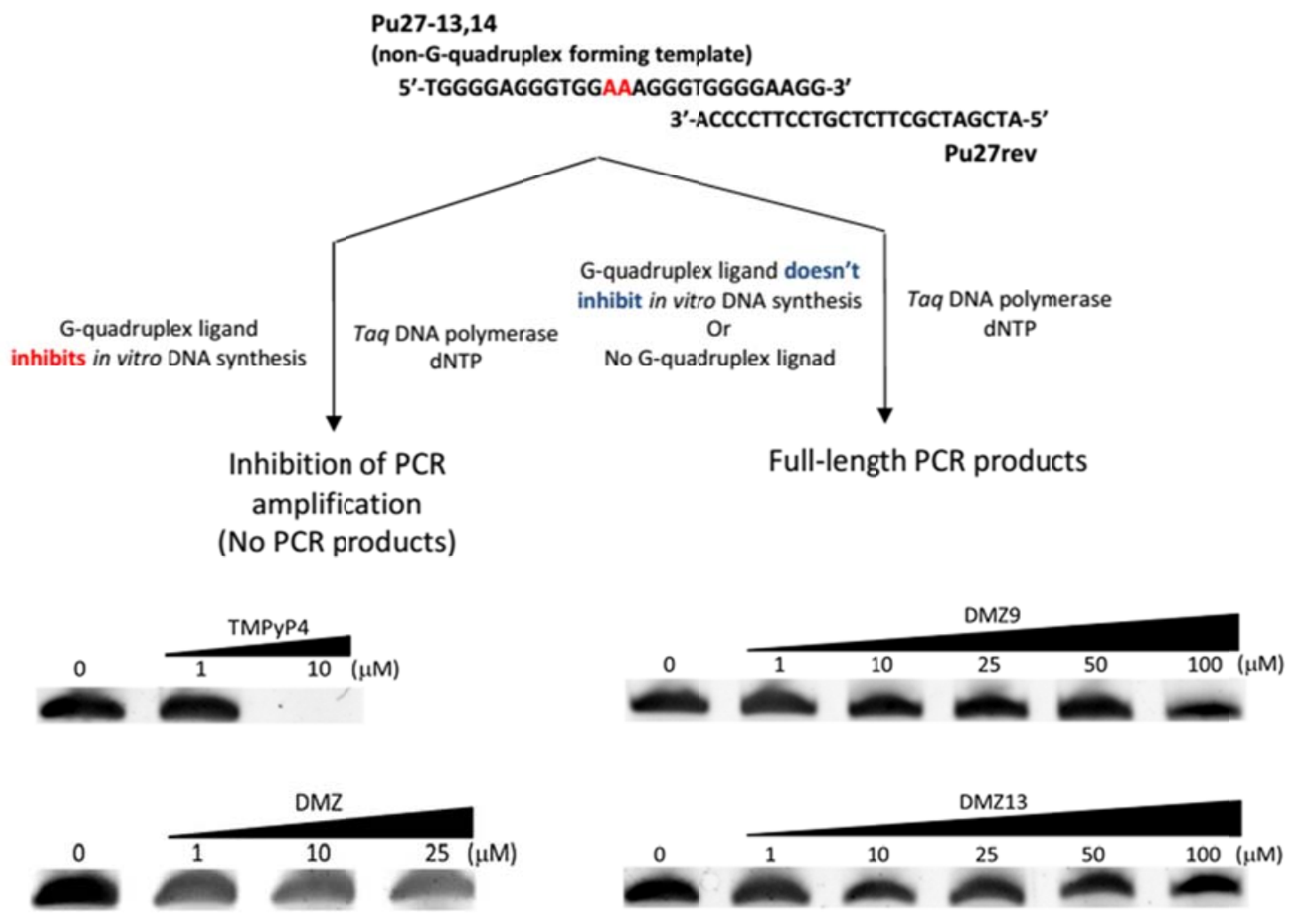

Fig. 7 Effects of DMZ analogues (DMZ1, DMZ 9, DMZ13), DMZ and TMPyP4 on the PCR stop assay with mutated c-MYC template Pu27-13,14. Compounds were added to the reaction mixture containing 1x PCR buffer (New England Biolabs), $5 \mu \mathrm{M}$ Pu27-13.14, $5 \mu \mathrm{M}$ Pu27rev, $200 \mu \mathrm{M}$ dNTPs and 5 units of Taq polymerase (New England Biolabs) separately. No compound added was treated as control.

The aforementioned experiments were performed to determine if alkyne-substituted analogues of DMZ, some of which have anti-cancer properties) interacted with G-quadruplex DNAs selectively (i.e. did not have affinity for duplex DNA). Although our in vitro studies revealed that these compounds are moderate G-quadruplex binders, it remained to be shown if the pharmacology of these compounds were via G-quadruplex stabilization inside cells. We proceeded to perform two classic experiments, which are traditionally done to show the in vivo efficacy of compounds via G-quadruplex stabilization: telomerase activity assay $^{29}$ or Western analysis of c-MYC expression ${ }^{24}$. 
Some G-quadruplex interactive ligands have been shown to achieve cancer cell killing via the inhibition of telomerase expression and/or inhibition of telomere extension. ${ }^{29}$ We therefore investigated if the anticancer activities of some of our analogues are derived (at least partially) from telomerase or telomere extension inhibition. We evaluated the effect of compounds DMZ9 and DMZ13 at various concentrations $\left(0.5 \times \mathrm{GI}_{50}, 1 \times \mathrm{GI}_{50}, 2 \times \mathrm{GI}_{50}\right)$ on telomerase activity in human breast cancer cell line (MDA-MB-231) using TRAPeze XL Telomerase Detection Kit (Intergen). TMPyP4 was evaluated at higher concentrations $\left(\left(1 \times \mathrm{GI}_{50}, 2 \times \mathrm{GI}_{50}, 4 \times \mathrm{GI}_{50}\right)\right.$ since it was less efficacious at cancer cell killing and so higher concentrations could be used and yet adequate amounts of cells would remain for post-treatment analysis.. Cells were treated with compounds for $48 \mathrm{~h}$ and $72 \mathrm{~h}$ respectively. Inhibition of telomerase was evaluated by comparing the telomerase activity in untreated cells. The results showed that telomerase activity in MDA-MB-231 could be inhibited by up to $50 \%$ after treating the cell lines with 11 $\mu \mathrm{M}\left(2 \times \mathrm{GI}_{50}\right)$ DMZ9 for $48 \mathrm{~h}$ or $72 \mathrm{~h}$ (see Fig. 8$)$. For TMPyP4, $25 \mu \mathrm{M}\left(2 \times \mathrm{GI}_{50}\right)$ could inhibit telomerase activity in MDA-MB-231 by $\sim 60$ and $80 \%$ for $48 \mathrm{~h}$ and $72 \mathrm{~h}$ respectively. It appears that the effect of DMZ9 on telomerase expression deceases over time whereas that of TMPyP4 increases over time. This could probably due to differential metabolism or degradation. Importantly the effects of both DMZ9 and TMPyP4 were dose-dependent. This was however not the case for DMZ13, which at 12.4 $\mu \mathrm{M}$ could inhibit about $20 \%$ and $30 \%$ of telomerase activity in MDA-MB-231 after treating the cells for $48 \mathrm{~h}$ and $72 \mathrm{~h}$ respectively (see Fig. 8). At $48 \mathrm{~h}$, the inhibition of telomerase activity by DMZ13 was not dose dependent. We currently do not have a hypothesis to explain this phenomenon but the low level of telomerase inhibition by DMZ13 suggests that its anti-cancer properties might be derived from the stabilization of other G-quadruplexes or even via a non-G-quadruplex stabilization pathway. The inhibition of telomerase expression could occur via several pathways. It has been proposed that this 
inhibition may be caused by the stabilization of G-quadruplex in the core promoter of hTERT (catalytic domain of telomerase) ${ }^{30}$ Also, hTERT is activated by c-MYC protein ${ }^{31}$ so the effects of analogue on telomerase inhibition could be an indirect one. Next, we performed a Western blot analysis of analogue DMZ9 and TMPyP4 on reducing c-MYC protein levels in MDA-MB-231 cells (see Fig. 9).
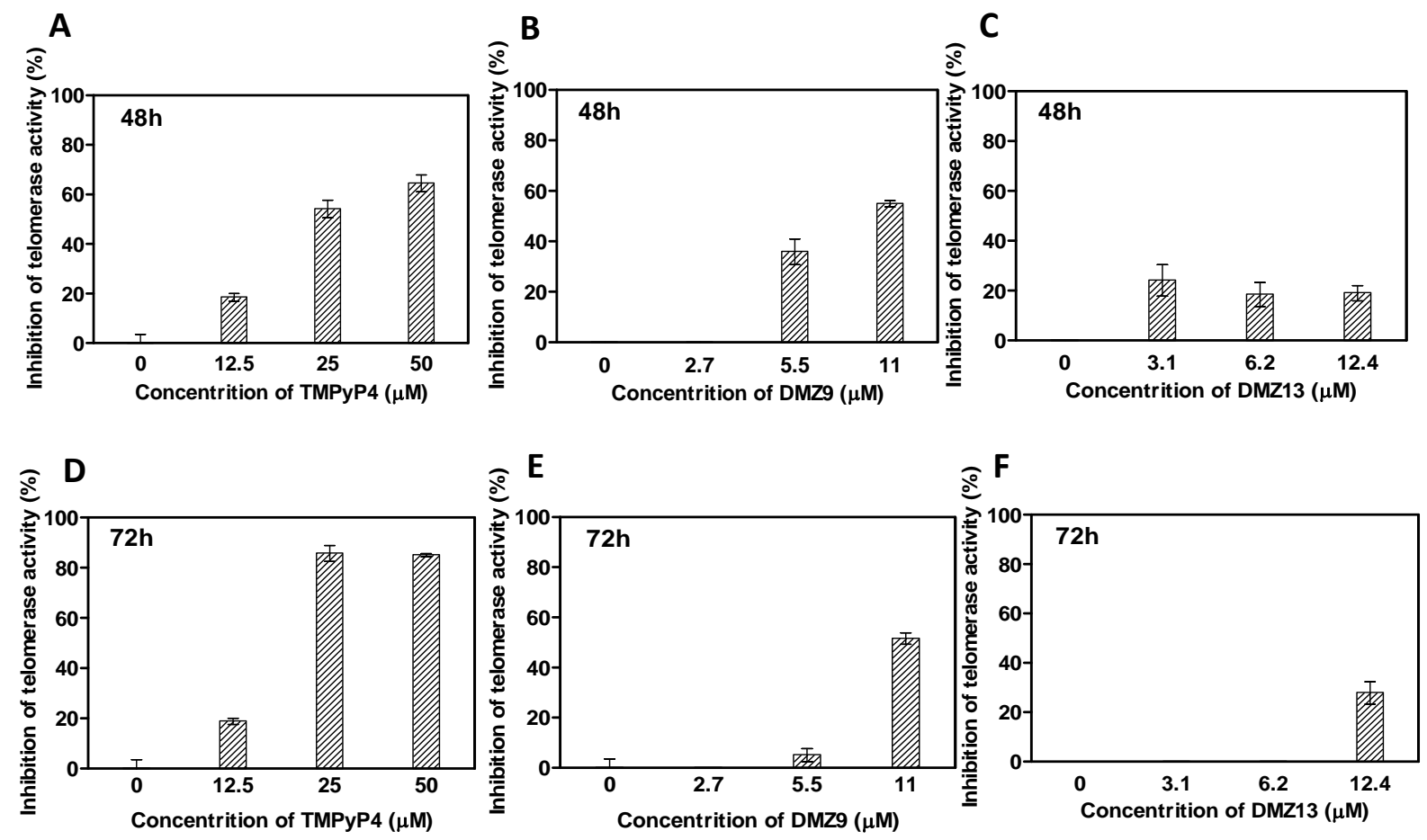

Fig. 8 Telomerase activity in lysates of TMPyP4-, DMZ9- or DMZ13-treated MDA-MB-231 cells for $48 \mathrm{~h}$ (upper panel) and $72 \mathrm{~h}$ (lower panel). Telomerase activity was determined using the TRAPeze XL Telomerase Detection Kit (Intergen). Lysate (1000 cell-equivalents) was mixed with TRAPeze XL reaction mix containing Amplifuor primers, and incubated for $30 \mathrm{~min}$ at $30{ }^{\circ} \mathrm{C}$. Telomerase products were quantitated using a Fluorescence plate reader. A, percentage inhibition of Telomerase activity in TMPyP4 treated MDA-MB-231 cells relative to untreated control is shown. B, percentage inhibition of telomerase activity in 916-1-treated MDA-MB-231 cells relative to untreated control is shown. C, percentage inhibition of telomerase activity in 1104-2-treated MDA-MB-231 cells relative to untreated control is shown

\section{Western Blot Analysis of c-MYC Protein Expression}


c-MYC protein levels in MDA-MB-231 cells were evaluated by performing Western Blot. MDA-MB-231

breast cancer cells were treated with 22.3 or $111.5 \mu \mathrm{M}$ TMPyP4, 5.45 or $27.25 \mu \mathrm{M}$ DMZ9 for 2, 6 or 24

h and $19.5 \mu \mathrm{M}$ DMZ13 for 6 or $24 \mathrm{~h}$. Here too, higher concentrations of TMPyP4 and DMZ13 than

DMZ9 could be used because TMPyP4 is not as efficacious as DMZ9 so higher concentrations could be used without killing all of the cells. TMPyP4 has previously been shown to down regulate c-MYC protein expression level $^{24}$ so TMPyP4 was included in this experiment as a positive control. The results showed that at $19.5 \mu \mathrm{M}$ DMZ13 had no effect on c-MYC expression at $6 \mathrm{~h}$ while at $27.25 \mu \mathrm{M}$ DMZ9 and 22.3 $\mu \mathrm{M}$ TMPyP4 caused an approximately 40\% decrease in the c-MYC protein expression at $6 \mathrm{~h}$. After $24 \mathrm{~h}$, DMZ13, DMZ9 and TMPyP4 caused 100\%, 67\% and 92\% reductions in c-MYC expression respectively. At a higher concentration of $111.5 \mu \mathrm{M}$, TMPyP4 caused a $100 \%$ reduction in c-MYC expression after 24 h (see Fig. 9). We conclude that both DMZ9 and DMZ13 down regulate c-MYC protein expression. Whether this is solely due to G-quadruplex stabilization or due to a combination of G-quadruplex stabilization and yet to be identified mechanism remains to be elucidated in future studies.
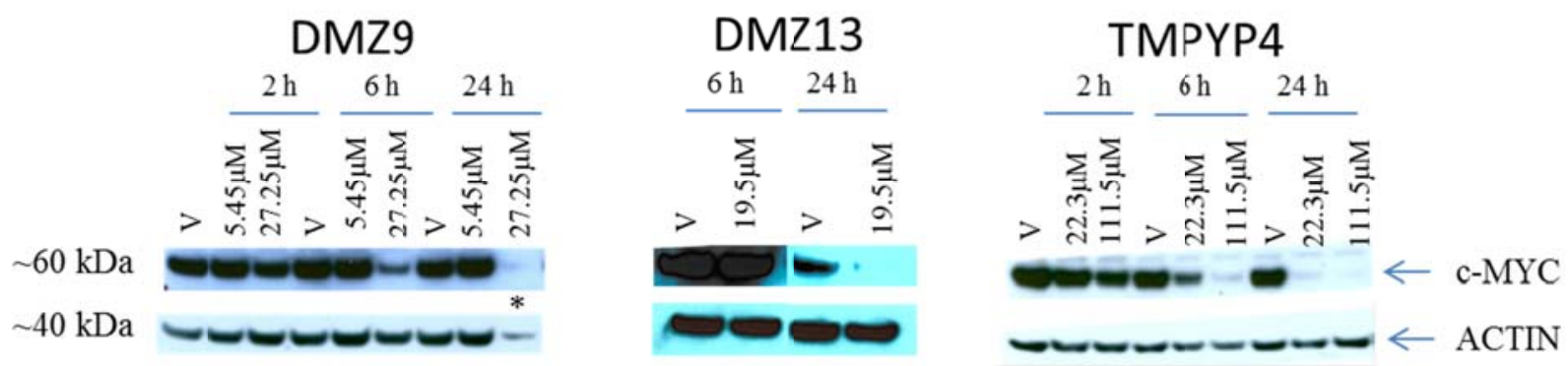

Fig. 9 Western Blot analysis of c-MYC protein expression in MDA-MB-231 after treated with DMZ9, DMZ13 and TMPyP4. MDA-MB-231 cells were treated with DMSO vehicle, DMZ9 (5.45 $\mu \mathrm{M}$ and $27.25 \mu \mathrm{M})$ and TMPyP4 $(22.3 \mu \mathrm{M}$ and $111.5 \mu \mathrm{M})$ for $2 \mathrm{~h}, 6 \mathrm{~h}$ and $24 \mathrm{~h}$. DMZ13 $(19.5 \mu \mathrm{M})$ for $6 \mathrm{~h}$ and $24 \mathrm{~h}$. Total protein was extracted and analyzed by Western Blot with 1:1,000 c-MYC (Cell Signaling) and 1:10,000 HRP-linked anti-rabbit IgG (Cell Signaling). *Observed high level of cytotoxicity and low protein levels. The graphs show the relative density as compared with the DMSO vehicle. Scanned images were analyzed using image $J$ software. 


\section{Conclusion}

DMZ analogues are easy to synthesize and monoamidine analogues that bear alkyne moieties are selective G-quadruplex binders with good anticancer properties. These alkyne derivatives of DMZ therefore serve as good lead molecules that warrant further studies. Key insights from this study are, G-quadruplex binding or selectivity are not sole determinants of anticancer efficacy, a fact that is increasingly being appreciated by the many workers in the field. For example TMPyP4 and DMZ stabilized G-quadruplexes far better than all of the alkyne-substituted DMZ analogues yet they were not the most efficacious anti-cancer agents. In fact $\mathbf{D M Z}$ was not effective at killing any of the three tested cancer cell lines. Secondly the majority of the DMZ analogues tested had similar G-quadruplex binding profile and selectivity yet the anticancer properties of these $\mathbf{D M Z}$ analogues varied greatly. Other factors, such as cell permeation or metabolism or sub-cellular localization or even alternative therapeutic target(s) could all come into play to modulate the efficacy of a particular agent. The synthetic tractability of the DMZ analogues makes it easy to make diverse libraries to screen and future efforts will be directed at expanding the DMZ library members and to increase the solubility profiles of the analogues. G-quadruplexes are emerging as important structural elements that regulate other disease states and so we anticipate that the molecules described in this manuscript and variants thereof could find utility in diverse areas, such as anti-HIV therapy.

\section{Experimental}

\section{General information}

Diminazene aceturate (DMZ), 4-aminobenzamidine dihydrochloride, cisplatin and most of aromatic amines were purchased from Sigma-Aldrich and used without further purification. DMZ1 was obtained 
following published $\quad$ procedure. $^{19(\mathrm{a})} \quad \alpha, \beta, \gamma, \delta$-Tetrakis(1-methylpyridinium-4-yl)porphyrin p-Toluenesulfonate (TMPyP4) was purchased from TCI America. 3-(Phenylethynyl)aniline and 3-(pyridin-2-ylethynyl)aniline were purchased from EnamineStore Ltd. c-kit1 22-mer (5'-AGG GAG GGC GCT GGG AGG GAG G-3'), F21T 21-mer (5'-FAM-GGG TTA GGG TTA GGG TTA GGG-TAMRA-3'), c-kit2 26-mer (5'-FAM-CCC GGG CGG GCG CGA GGG AGG GGA GG-TAMRA-3'), k-RAS21R 21-mer (5'-FAM-AGG GCG GTG TGG GAA GAG GGA-TAMRA-3'), c-MYC 22-mer (5'-FAM-TGA GGG TGG GTA GGG TGG GTA A-TAMRA-3'), duplex 26-mer (5'FAM-TAT AGC TAT ATT TTT TTA TAG CTA TA-TAMRA-3') and duplex competitor 26-mer DNA (5'-CAA TCG GAT CGA ATT CGA TCC GAT TG-3') were purchased from IDT, where FAM is 6-carboxyfluorescein and TAMRA is 6-carboxytetramethylrhodamine. The concentrations of DNA stock solutions were determined by measuring the absorbance at $260 \mathrm{~nm}$ using the extinction coefficient values published in the literature. ${ }^{32}$ Nuclear magnetic resonance (NMR) spectra were recorded on Bruker DRX-400 MHz instrument $\left({ }^{1} \mathrm{H}, 400 \mathrm{MHz} ;{ }^{13} \mathrm{C}, 100 \mathrm{MHz}\right)$ or Bruker DRX-500 MHz instrument $\left({ }^{1} \mathrm{H}, 500\right.$ $\left.\mathrm{MHz} ;{ }^{13} \mathrm{C}, 125 \mathrm{MHz}\right)$. Data for ${ }^{1} \mathrm{H}$ NMR and ${ }^{13} \mathrm{C}$ spectra were recorded as follows: chemical shift $(\delta$, ppm), multiplicity (s, singlet; d, doublet; t, triplet; q, quartet; m, multiplet), integration, coupling constant (Hz). High-resolution mass spectra (HRMS) have been obtained by a TOF instrument with ESI positive mode as the ionization method.

\section{Synthesis of the DMZ analogues}

(1) Synthesis of alkyne-substituted aromatic amines via Sonogashira coupling. 

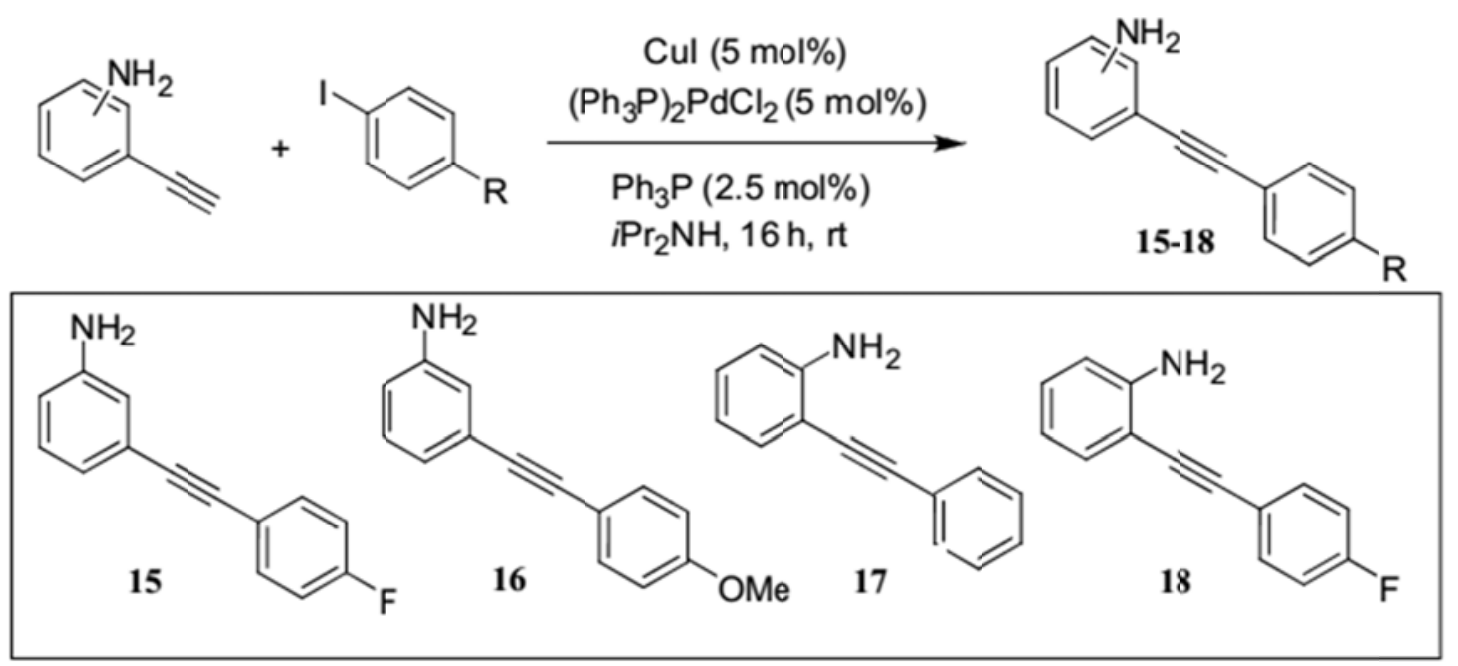

Scheme 1 Sonogashira coupling to prepare compounds 15-18.

The syntheses of alkyne-substituted aromatic amines (15-18) followed the general Scheme 1. A $50 \mathrm{~mL}$ Schlenk flask was charged with aryl iodide ( $2 \mathrm{mmol}, 1.0$ eq.), bis-(triphenylphosphine) palladium dichloride (70 mg, 0.05 eq.), cuprous iodide (10 mg, 0.05 eq.), triphenylphosphine (13 mg, 0.025 eq.), and a stir bar and sealed with rubber septum. ${ }^{33}$ The flask was evacuated and refilled three times with Argon. Ethynylaniline (1.1 eq.) was added to $10 \mathrm{~mL}$ of distilled dry $i \operatorname{Pr}_{2} \mathrm{NH}$ and degassed together in a separated round bottom flask for 15 minutes and then transferred to the Schlenk flask through cannula. The mixture was stirred for $16 \mathrm{~h}$ at room temperature $\left(65{ }^{\circ} \mathrm{C}\right.$ in the case of aryl bromide). After completion of the reaction, the mixture was diluted with ethyl acetate $(50 \mathrm{~mL})$ and the slurry was filtered through a pad of Celite in a sintered glass funnel (medium frit). The tan solids were additionally washed with ethyl acetate until the filtrate was nearly colorless. The filtrate was washed with $\mathrm{H}_{2} \mathrm{O}$ and brine and dried over magnesium sulfate. The combined organic fraction filtrates were concentrated in vacuum, yielding a black solid. The residue was further purified by flash column chromatography on silica gel using ethyl acetate/hexane mixture as eluent. 


\section{(2) General procedure for the synthesis of DMZ analogues.}

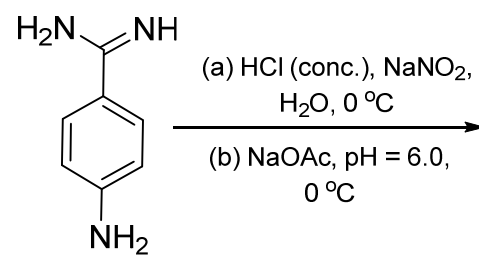

19

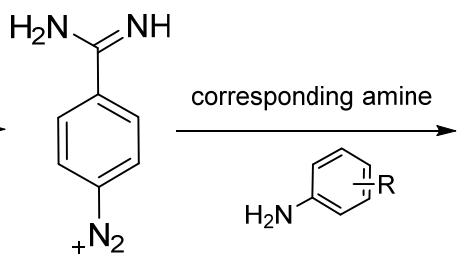

20<smiles>[R]c1ccc(NN=Nc2ccc(C(=N)N)cc2)cc1</smiles>

DMZ1-14

Scheme 2 Facile synthesis of DMZ analogues via diazonium intermediates. Staibility test is shown in Figure S6.

The synthesis of DMZ analogues followed previously reported procedure, ${ }^{19(a)}$ see Scheme 2 . 4-Aminobenzamidine dihydrochloride $(212 \mathrm{mg}, 1.0 \mathrm{mmol})$ was added to a stirred solution of $12 \mathrm{~N} \mathrm{HCl}$ $(0.27 \mathrm{~mL})$ and water $(1.5 \mathrm{~mL})$ in a $10 \mathrm{~mL}$ flask at $0{ }^{\circ} \mathrm{C}$ and stirring was continued for $15 \mathrm{~min}$. To the mixture was added (dropwise) cold $\left(\sim 0{ }^{\circ} \mathrm{C}\right) \mathrm{NaNO}_{2}$ solution $(76 \mathrm{mg}$ in $0.27 \mathrm{~mL}$ water, 1.1 eq.) and stirring was continued for $15 \mathrm{~min}$ before cold $\left(\sim 0{ }^{\circ} \mathrm{C}\right) \mathrm{NaOAc}$ solution (328 mg in $1.5 \mathrm{~mL}$ water, 4.0 eq.) was added dropwise over $15 \mathrm{~min}$ to adjust the $\mathrm{pH}$ to 6.0 . Cold $\left(\sim 0{ }^{\circ} \mathrm{C}\right)$ aromatic amine solution $(1.0 \mathrm{mmol}$ in $1.0 \mathrm{~mL}$ methanol) was added dropwise to the above solution and stirring was continued for another 1-12 h at $0{ }^{\circ} \mathrm{C}$. After the reaction was completed, the solvent was removed under reduced pressure. Water $(100 \mathrm{~mL})$ was added to the residue and the aqueous mixture was washed with dichloromethane $(2 \times 15$ $\mathrm{mL}$ ). The aqueous layer was then basified with $2.5 \% \mathrm{NaOH}$ solution to make the $\mathrm{pH}>10.0$. The desired compound was then extracted from the aqueous layer with ethyl acetate $(2 \times 100 \mathrm{~mL})$. The organic layer was washed with brine and dried with sodium sulfate. Finally, the solvent was removed under reduced pressure and the final product was obtained with purity $>95 \%$.

\section{Cell lines and culturing.}

The following human cell lines were purchased from ATCC (ATCC, Manassas, VA): prostate cancer cells 
(PC-3), triple negative breast cancer cells (MDA-MB-231), ovarian cancer cells (OVCAR-3), normal bone marrow (NBM) and normal fibroblast cells (MCR5A). MDA-MB-231 cells were grown at $37{ }^{\circ} \mathrm{C}$ with 5\% $\mathrm{CO}_{2}$ atmosphere with DMEM (Life technologies, Carlsbad, CA) supplemented with heat-inactivated $10 \%(\mathrm{~V} / \mathrm{V})$ fetal bovine serum. OVCAR-3 and PC-3 cells were grown at $37{ }^{\circ} \mathrm{C}$ with $5 \%$ $\mathrm{CO}_{2}$ atmosphere with RPMI (Life technologies, Carlsbad, CA) supplemented with heat-inactivated 10\% $(\mathrm{V} / \mathrm{V})$ fetal bovine serum. Cell lines were grown and maintained according to ATCC recommendations.

\section{$\mathbf{G I}_{50}$ determination.}

Cell lines were seeded into 96-well plates the afternoon prior to treatment. Cell seeding number was determined by growing cells in log phase growth during drug treatment. Approximately $18 \mathrm{~h}$ later, compounds were semi-serially diluted in dimethyl sulfoxide (DMSO) and then growth medium, and added to cells. Plates were incubated for $72 \mathrm{~h}$ prior to addition of WST-1 (Promega, Madison WI). Plates were read after 4 additional hours of incubation at $37{ }^{\circ} \mathrm{C}$ using a Bio-Tek Synergy HT plate reader (Bio-Tek, Winooski, VT). Data was analyzed, graphed and $\mathrm{GI}_{50} \mathrm{~S}$ generated using GraphPad Prism Software (Graphpad, La Jolla, CA).

Fluorescence resonance energy transfer (FRET) assay to determine $T_{1 / 2}$ in absence and presence of ligands.

All dual-labelled DNAs were diluted from stock $(50 \mu \mathrm{M})$ to $800 \mathrm{nM}$ in $60 \mathrm{mM}$ potassium cacodylate buffer $\left(\mathrm{pH}\right.$ 7.2) and then annealed by heating at $85^{\circ} \mathrm{C}$ for $10 \mathrm{~min}$ followed by cooling to room temperature in the heating block, following literature precedent ${ }^{22}$. Compounds were diluted from stock (20 $\mathrm{mM}$ in DMSO) to $8 \mu \mathrm{M}$ in $60 \mathrm{mM}$ cacodylate buffer (pH 7.2). $25 \mu \mathrm{L}$ annealed DNA was added to 
96-well plate followed by $25 \mu \mathrm{L}$ diluted compounds. Samples were then allowed to incubate for at least $12 \mathrm{~h}$ at $4{ }^{\circ} \mathrm{C}$ to come to equilibrium. Measurements were made in triplicate by using a LightCycler 480 System RT-PCR machine (Roche) and average values were reported. Fluorescence readings were made with excitation at $450-495 \mathrm{~nm}$ and detection at $515-545 \mathrm{~nm}$, taken at intervals of $1.2^{\circ} \mathrm{C} / \mathrm{min}$ in the range $25^{\circ} \mathrm{C}$ to $95^{\circ} \mathrm{C}$. The sequences of labelled oligonucleotides were as follows : F21T 21-mer (5'-FAM-GGG

TTA GGG TTA GGG TTA GGG-TAMRA-3'), c-kit2 26-mer (5'-FAM-CCC GGG CGG GCG CGA GGG AGG GGA GG-TAMRA-3'), k-RAS21R 21-mer (5'-FAM-AGG GCG GTG TGG GAA GAG GGA-TAMRA-3'), c-MYC 22-mer (5'-FAM-TGA GGG TGG GTA GGG TGG GTA A-TAMRA-3') and duplex 26-mer (5'-FAM-TAT AGC TAT ATT TTT TTA TAG CTA TA-TAMRA-3’).

\section{FRET DNA melting in competition with duplex DNA}

FRET competition assay was performed by adding $4 \mu \mathrm{M}, 40 \mu \mathrm{M}$ and $200 \mu \mathrm{M}$ duplex competitor 26 -mer DNA (5'-CAA TCG GAT CGA ATT CGA TCC GAT TG-3') in the presence of $0.4 \mu \mathrm{M}-M Y C$ G-quadruplex and $4 \mu \mathrm{M}$ DMZ analogues. Both c-MYC G-quadruplex and duplex competitor 26-mer DNA were diluted in $60 \mathrm{mM}$ potassium cacodylate buffer $(\mathrm{pH} 7.2)$ and then annealed by heating at $85{ }^{\circ} \mathrm{C}$ for $10 \mathrm{~min}$ followed by cooling to room temperature in the heating block. Experiments were performed in triplicate.

\section{PCR Stop Assay}

This assay was performed by modifying a previously published protocol. ${ }^{34}$ Sequences of the tested oligomers, Pu27, Pu27-13,14, Pu-mutant and the corresponding complementary oligomer Pu27rev were presented in Table 2. 
Table 2. Sequences of Oligomers used in the PCR Stop Assay

\begin{tabular}{|c|c|c|}
\hline Name of Oligomers & Sequence & Description \\
\hline $\mathrm{Pu} 27$ & 5'-TGGGGAGGGTGGGGAGGGTGGGGAAGG-3' & $\begin{array}{l}\text { Partial sequence of promoter of } \\
\text { oncogene c-MYC. }\end{array}$ \\
\hline \multirow[t]{2}{*}{$\mathrm{Pu} 27-13,14$} & 5'-TGGGGAGGGTGGAAAGGGTGGGGAAGG-3' & $\begin{array}{l}\text { A mutated Pu27 (a control template) } \\
\text { whose guanines at } 13^{\text {th }} \text { and } 14^{\text {th }} \\
\text { positions were changed to } \\
\text { adenosines. }\end{array}$ \\
\hline & & Another mutated Pu27 (another \\
\hline Pu-mutant & 5'- TGGAGAGAGTGGAAAGAGTGGGGAAGG-3' & $\begin{array}{l}\text { control template) whose qunines at } \\
4^{\text {th }}, 8^{\text {th }}, 13^{\text {th }}, 14^{\text {th }} \text { and } 17^{\text {th }} \text { positions } \\
\text { were changed to adenosines. }\end{array}$ \\
\hline $\mathrm{Pu} 27 \mathrm{rev}$ & 5'-ATCGATCGC TTCTCGTCCTTCCCCA-3' & Complementary sequence of Pu27 \\
\hline
\end{tabular}

To the PCR reaction mixture $(25 \mu \mathrm{L}), 1 \times$ PCR buffer (New England Biolabs), $5 \mu \mathrm{M}$ Pu27 and Pu27rev

oligomers, various concentrations of ligands (DMZ, TMPyP4, DMZ1, DMZ9 and DMZ13) were added and incubated at $4{ }^{\circ} \mathrm{C}$ for $6 \mathrm{~h}$. After that, $200 \mu \mathrm{M}$ dNTPs, 5 units of Taq DNA polymerase (New England Biolabs) were added and PCR reactions were performed in a thermocycler, with the following conditions: $94{ }^{\circ} \mathrm{C}$ for $3 \mathrm{~min}$, followed by 20 repeated cycles each having $94{ }^{\circ} \mathrm{C}$ for $30 \mathrm{~s}, 58{ }^{\circ} \mathrm{C}$ for $30 \mathrm{~s}$, and $72{ }^{\circ} \mathrm{C}$ for 30 s. After PCR, amplified products were analyzed on $12 \%$ polyacrylamide gel with $1 \times$ TBE and SYBR Gold stained. This assay was also performed under the same conditions with $\mathrm{Pu} 27-13,14$ and Pu27rev, and Pu-mutant and Pu27rev.

\section{Telomerase Activity Assay}

MDA-MB-231 cells were routinely cultured in DMEM with 10\% FBS and 1\% L-glutamine. The evening prior to treatment, actively growing MDA-MB-231 cells were sub-cultured and seeded into T-25 flasks at $2 \times 10^{5}$ cells/flask. The following morning, cells were treated with vehicle, DMZ9, DMZ13, or TMPyP4 at $0.5 \times, 1 \times$, or $2 \times \mathrm{GI}_{50}$. At 48 and $72 \mathrm{~h}$ after treatment, cells were harvested, washed with PBS, and pelleted. Cell pellets were resuspended in $200 \mu$ CHAPS lysis buffer with 200 units/mL RNase 
inhibitor, mixed by pipetting, and incubated on ice for 30 minutes. Lysates were then centrifuged at $12,000 \times \mathrm{g}$ for 20 minutes at $4^{\circ} \mathrm{C}$, and supernatants were collected, snap frozen and stored at $-80{ }^{\circ} \mathrm{C}$ until analysis. Telomerase activity was assayed using a fluorescence-based TRAPeze XL telomerase detection kit (Intergen, Purchase, NY). According to manufacturer, lysates (1000 cell- equivalents) were mixed with TRAPeze XL reaction mix containing Amplifuor primers and incubated at $30^{\circ} \mathrm{C}$ for 30 min to allow the elongation of "TS" primer by telomerase. Amplified telomerase products were quantitated with a fluorescence plate reader. Telomerase activity (in TPG units) was calculated by comparing the ratio of telomerase products to an internal standard for each lysate, as described by the manufacturer. Each unit of TPG (Total Product Generated) corresponds to the number of TS primers extended with at least 3 telomeric repeats by telomerase in the extract in a 30 minute incubation at $30{ }^{\circ} \mathrm{C}$

\section{Western Blot}

MDA-MB-231 cells in exponential growth were treated with either DMSO vehicle, DMZ9 at 5.45 or $27.25 \mu \mathrm{M}$, or or DMZ13 at $19.5 \mu \mathrm{M}$ or TMPYP4 at 22.3 or $111.5 \mu \mathrm{M}$, for a period of 6 , or $24 \mathrm{~h}$. At each time point the cells were harvested, washed with 1x PBS and lysed in radioimmunoprecipitation (RIPA) buffer with protease inhibitors. The protein in the resulting lysates was quantified using BCA (Pierce) and subjected to SDS PAGE, then subsequently transferred for Western blot analysis with 1:1,000 c-MYC (Cell Signaling) and 1:10,000 HRP-linked anti-rabbit IgG (Cell Signaling). Scanned images were analyzed for densitometry using ImageJ software and $\beta$-actin as a loading control. Conditions were compared by percent to vehicle control for each time point.

\section{Acknowledgement}


We thank NSF (Award\# CHE 1518006) and UMD Graduate Dean's Dissertation Fellowship (JZ) for funding.

\section{References}

1. (a) (1) http://www.cancer.gov/about-cancer/treatment/types; (b) I. Melero, G. Gaudernack, W. Gerritsen, C. Huber, G. Parmiani, S. Scholl, N. Thatcher, J. Wagstaff, C. Zielinski, I. Faulkner, H. Mellstedt, 11 (2014) Nat. Rev. Clin. Oncol. 509-524.

2. K. L. Jones, A.U. Buzdar, 11 (2004) Endocr. Relat. Cancer. 391-406.

3. C.D. Hart, I. Migliaccio, L. Malorni, C. Guarducci, L. Biganzoli, A. Di Leo, 12 (2015) Nat. Rev. Clin. Oncol. 541-552.

4. S. Balasubramanian, L.H. Hurley, S. Neidle, 10 (2011) Nat. Rev. Drug Discov. 261-275.

5. M.L. Bochman, K. Paeschke, V.A. Zakian, 13 (2012) Nat. Rev. Genet. 770-780.

6. G.W. Collie, G.N. Parkinson, 40 (2011) Chem. Soc. Rev. 5867-5892.

7. D. Gomez, T. Lemarteleur, L. Lacroix, P. Mailliet, J.L. Mergny, J.F. Riou, 32 (2004) Nucleic Acids Res. 371-379.

8. M. Melko, B. Bardoni, 92 (2010) Biochimie. 919-926.

9. M. Gunaratnam, M. de la Fuente, S.M. Hampel, A.K. Todd, A.P. Reszka, A. Schätzlein, S. Neidle, 19 (2011) Bioorg. Med. Chem. 7151-7157.

10. J.C. Grigg, N. Shumayrikh, D. Sen, 9 (2014) PLoS One e106449.

11. (a) P. Travascio, Y. Li, D. Sen, 5 (1998) Chem. Biol. 505-517; (b) S. Nakayama, H.O. Sintim, 131 (2009) J. Am. Chem. Soc. 10320-10333; (c) E. Golub, R. Freeman, I. Willner, 50 (2011) Angew. Chem. Int. Ed. 11710-11714.

12. H.J. Lipps, D. Rhodes, 19 (2009) Trends Cell Biol. 414-422.

13. (a) A. Siddiqui-Jain, C.L. Grand, D.J. Bearss, L.H. Hurley, 99 (2002) Proc. Natl. Acad. Sci. U. S. A. 11593-11598; (b) A.M. Burger, F.P. Dai, C.M. Schultes, A.P. Reszka, M.J. Moore, J.A. Double, S. Neidle, 65 (2005) Cancer Res. 1489-1496; (c) P.S. Shirude, E.R. Gillies, S. Ladame, F. Godde, K. Shin-Ya, I. Huc, S. Balasubramanian, 129 (2007) J. Am. Chem. Soc. 11890-11891; (d) M. Kaiser, A. De Cian, M. Sainlos, C. Renner, J.L. Mergny, M.P. Telaude-Fichou, 4 (2006) Org. Biomol. Chem. 1049-1057.

14. B. Brassart, D. Gomez, A. De Cian, R. Paterski, A. Montagnac, K.H. Qui, N. Temime-Smaali, C. Trentesaux, J.L. Mergny, F. Gueritte, J.F. Riou, 72 (2007) Mol. Pharmacol. 631-640.

15. A.T. Phan, V. Kuryavyi, H.Y. Gaw, D.J. Patel, 1 (2005) Nat. Chem. Biol. 167-173.

16. M. Bejugam, S. Sewitz, P. S. Shirude, R. Rodriguez, R. Shahid, S. Balasubramanian, 129 (2007) J. Am. Chem. Soc. 12926-12927.

17. (a) S.M. Kerwin, 6 (2000) Curr. Pharm. Des. 441-478; (b) L. Oganesian, T.M. Bryan, 29 (2007) Bioessays 155-165.

18. M. Hagihara, L. Yamauchi, A. Seo, K. Yoneda, M. Senda, K. Nakatani, 132 (2010) J. Am. Chem. Soc. 11171-11178.

19. (a) J. Zhou, V. Le, D. Kalia, S. Nakayama, C. Mikek, E.A. Lewis, H.O. Sintim, 10 (2014) Mol. Biosyst. 2724-2734. (b) G.L. da Silva Oliveira, R.M. de Freitas, 102 (2015) Pharmacol. Res. 138-157.

20. (a) J. Lavrado, H. Brito, P.M. Borralho, S.A. Ohnmacht, N. Kim, C. Leitão, S. Pisco, M. Gunaratnam, C.M.P. Rodrigues, R. Moreira, S. Neidle, A. Paulo. 5 (2015) Sci. Rep. 9696; (b) Y. Yan, J. Tan, T. Ou, Z. Huang, L. Gu. 23 (2013) Expert Opin. Ther. Pat. 1495-1509.

21. T.A. Brooks, L.H. Hurley, 1 (2010) Genes Cancer 641-649.

22. J. Lavrado, H. Brito, P. M. Borralho, S. A. Ohnmacht, R.E. Castro, C.M.Rodrigues, R.Moreira, D.J. dos Santos, S. Neidle, A. Paulo, 8 (2013) ChemMedChem, 1648-1661. 
23. (a) Q. Yang, J. Xiang, S. Yang, Q. Li, Q. Zhou, A. Guan, X. Zhang, H. Zhang, Y. Tang, G. Xu, 38 (2010) Nucleic Acids Res. 1022-1033; (b) B.H. Geierstanger, D.E. Wemmer, 24 (1995) Annu. Rev. Biophys. Biomol. Struct. 463-493; (c) X.G. Han, X.L. Gao, 8 (2001) Curr. Med. Chem. 551-581.

24. C.L. Grand, H. Han, R.M. Muñoz, S. Weitman, D.D. Von Hoff, L.H. Hurley, D.J. Bearss, 1 (2002) Mol. Cancer Ther. 565-573.

25. (a) J.N. Liu, R. Deng, J.F. Guo, J.M. Zhou, G.K. Feng, Z.S. Huang, L.Q. Gu, Y.X. Zeng, X.F. Zhu, 21 (2007) Leukemia 1300-1302; (b) M. Tera, H. Ishizuka, M. Takagi, M. Suganuma, K. Shin-ya, K. Nagasawa, 47 (2008) Angew. Chem. Int. Ed. Engl. 5557-5560; (c) D. Gomez, T. Lemarteleur, L. Lacroix, P. Mailliet, J.L. Mergny, J.F. Riou, 32 (2004) Nucleic Acids Res. 371-379.

26. T.M. Ou, Y.J. Lu, C. Zhang, Z.S. Huang, X.D. Wang, J.H. Tan, Y. Chen, D.L. Ma, K.Y. Wong, J.C. Tang, A.S. Chan, L.Q. Gu, 50 (2007) J. Med. Chem. 1465-1474.

27. I. Wierstra, J. Alves, 99 (2008) Adv. Cancer Res. 113-333.

28. A. De Cian, G. Cristofari, P. Reichenbach, E. De Lemos, D. Monchaud, M.P. Teulade-Fichou, K. Shin-Ya, L. Lacroix, J. Lingner, J.L. Mergny, 104 (2007) Proc. Natl. Acad. Sci. U. S. A. 17347-17352.

29. J.F. Riou, L. Guittat, P. Mailliet, A. Laoui, E. Renou, O. Petitgenet, F. Mégnin-Chanet, C. Hélène, J.L. Mergny, 99 (2002) Proc. Natl. Acad. Sci. U. S. A. 2672-2677.

30. S.L. Palumbo, S.W. Ebbinghaus, L.H. Hurley, 131 (2009) J. Am. Chem. Soc. 10878-10891.

31. J. Wang, L.Y. Xie, S. Allan, D. Beach, G.J. Hannon, 12 (1998) Genes Dev. 1769-1774.

32. N. Kumar, S. Maiti, 33 (2005) Nucleic Acids Res. 6723-6732.

33. E. Christiansen, C. Urban, N. Merten, K. Liebscher, K.K. Karlsen, A. Hamacher, A. Spinrath, A.D. Bond, C. Drewke, S. Ullrich, M.U. Kassack, E. Kostenis, T. Ulven, 51 (2008) J. Med. Chem. 7061-7064.

34. N. Nagesh, G. Raju, R. Srinivas, P. Ramesh, M.D. Reddy, C.R. Reddy, 1850 (2015) Biochim. Biophys. Acta. 129-140. 
